3 See The Chester Plays, adapted as an acting text by Alexandra Johnston, assisted by Linda Phillips (2010), from the modernized version by David Mills: available as PDF pages at <http://www.reed.utoronto.ca/chester/> and < http://www.reed. utoronto.ca/play-texts.html $>$. All quotations from the text offer line references given parenthetically. See also David Mills (ed.), The Chester Mystery Cycle: A New Edition with Modernised Spelling, Medieval Texts and Studies 9 (East Lansing, MI, 1992).

4 Alexandra F. Johnston, 'The Chester Text 2010', a paper delivered at the Chester 2010 symposium, Drama and Religion 1555-1575: The Chester Cycle in Context, University of Toronto, 21 May 2010.

5 Erin E. Kelly, 'Doubt and Religious Drama Across Sixteenth-Century England', Drama and Religion 1555-1575: The Chester Cycle in Context, 23 May 2010.

6 REED: Cheshire Including Chester (Toronto, 2007), 143. See also <http://chester .uwaterloo.ca/index.php/chester/performance/goodman_letters $>$.

7 Reprinted in The Collected Papers of Frederic William Maitland, ed. H.A.L. Fisher (Cambridge, 1911), 3.449.

8 I admit a certain bias regarding this play: as an MA student in 1983 I co-directed my first medieval drama production, 'The Massacre of the Innocents' featuring Alexandra F. Johnston herself as Angel; I also played the role of the devil, for whom I continue to advocate here.

9 Johnston, 'The Chester Text 2010'.

10 See the previous note. In 1983, we innocently played both 'alternative' stanzas but were told by editor David Mills that we made the apparent duplication work reasonably well, theatrically.

11 David Mills, Recycling the Cycle: The City of Chester and its Whitsun Plays (Toronto, 1998), 184.

\title{
Playing to the (Twenty-First Century) Crowd: On the Ground at Chester 2010
}

My claim to an 'on-the-ground' perspective is first and foremost literal. I came to Chester 2010 as a seasoned reader of medieval plays, a veteran stagemanager, and an occasional actor. But the Chester Cycle was to be my first experience of a full-scale early English drama production, and I was determined to attend the plays as an audience member first and a scholar second. I didn't want critical distance; I wanted to participate, to interact. So as the performances were about to begin I grabbed my beach towel and camera and 
found myself a prime spot, right in front on the grass at station two. And there I stayed despite the periodic rain of day one and the blazing sun of days two and three. I talked with musicians, a few disciples, and a God or two; I was merrily cursed by Balaack; I was even whacked in the head by a stuffed pelican (I'll come back to this in a moment).

But I also claim an 'on-the-ground' perspective in that my focus here is not only on the Chester 2010 plays themselves but also what they meant to my fellow audience members. In the (often lengthy) waits between plays, over the whir of (all-too-modern) power tools used to bring forth Eden, heaven, and other biblical settings, I met lots of great people and had many enlightening conversations. I chatted with long-time Poculi Ludique Societas patrons, with moms who wanted their young children to see favourite Bible stories brought to life, and with passing dog walkers who stopped to see a play and then came back for more the next day. Despite the difficulty in calling out only a handful of moments from the nearly twenty hours of performances throughout the weekend, the discussion that follows will, I hope, highlight some of the reasons why postmodern audiences continue to be drawn to medieval theatre, to find it relevant in our hectic, media-driven, overly-programmed society.

As part of her efforts to recreate the 1572 cycle as Christopher Goodman saw it, Alexandra Johnston combined the episode of Abraham and Isaac with that of Moses and the Ten Commandments into a single play that was presented by Ryerson University. The Expositor skilfully provided the bridge between the two episodes. Like others at Chester 2010, the Ryerson troupe chose to play their Expositor for laughs, a tactic that the crowd much appreciated. Dressed in cassock and biretta and played as a brash, interfering figure, he provided a few hearty anticlerical laughs. His role was one of interruption, rather than interpretation: even God showed his impatience with the Expositor, drumming his fingers on the celestial throne as the Expositor tried to upstage first Abraham and then Moses. Finally, God himself cut off the Expositor's lengthy speeches, leaving the latter to pout theatrically as the action continued despite him.

Well-paced humour characterized the play. Those in the audience will remember Moses's triumphant extraction of two perfectly formed tablets from a mountain of stone following a few brief taps with a chisel. God's incredulity at Moses's confusion over what to carve on his second set of tablets provided another gratifying moment; the Father's response, 'thou shalt write the same lore / that in the tables was before', had the frustrated intonation of a parent 
providing the same set of directions for the umpteenth time. Yet the Abraham and Isaac episode was also among the most touching of the whole cycle, showing the Ryerson troupe's sensitivity to the wide range of emotion that characterizes medieval drama. Abraham was clearly broken-hearted in his obedience, trying hard to follow God's command but also swayed by his son's cry for mercy. Isaac's willingness to die at his father's hand was not mitigated by his repeated attempts to defer the sacrifice; his request for his father's blessing, his concern for his mother and brothers, even his entreaty that his father take care not to ruin his clothing struck a poignant balance between fear and acceptance, confusion and consent. It was impossible not to recall the loving interactions between father and son during the Passion sequence on day two: this was truly affective, and effective, typological theatre.

The play concluded with a perfect blend of reverence and humour as the full cast assembled at the front of the wagon for a rousing chorus of 'Amens' sung in a capella harmony. The eyes of the cast twinkled each time their tune seemed to reach a natural conclusion and they began a new round with even more gusto. The longer they sang, the more infectious the crowd's

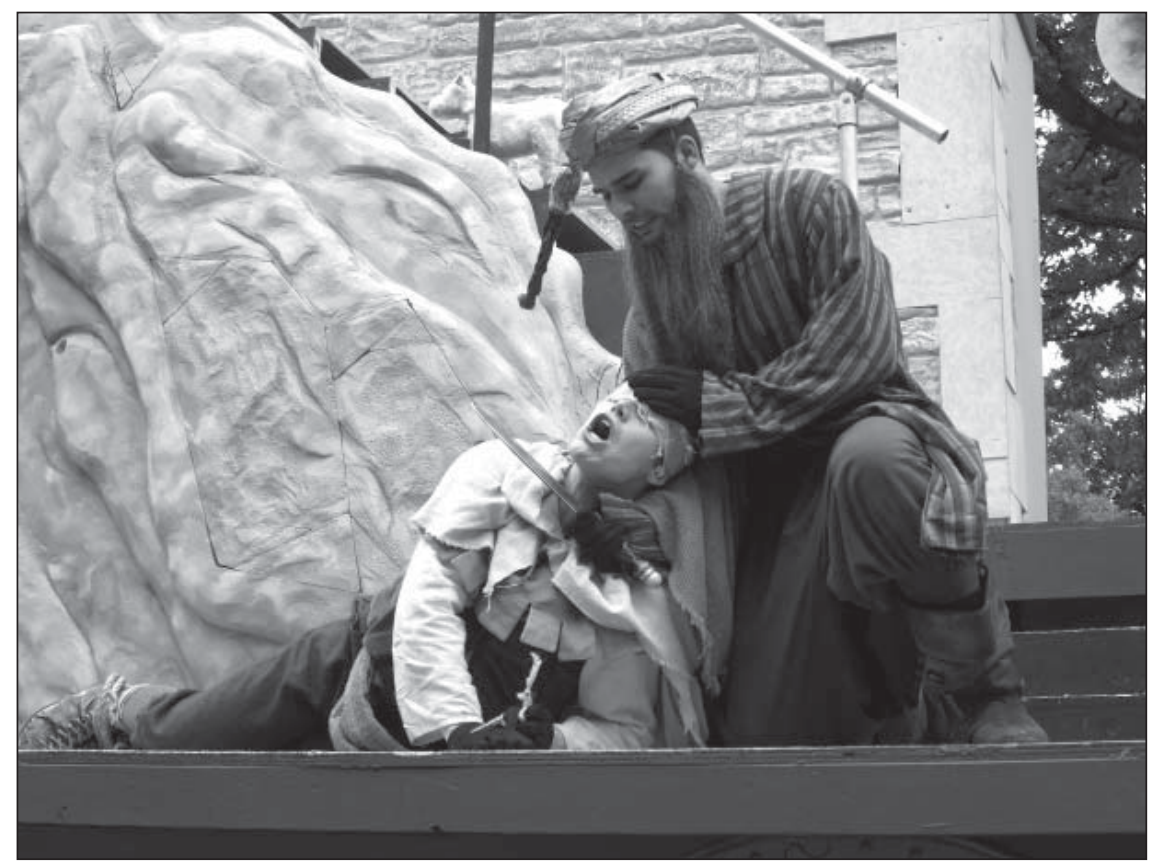

Fig. 3. Abraham and Isaac (Ryerson University). Courtesy of Heather S. Mitchell. 


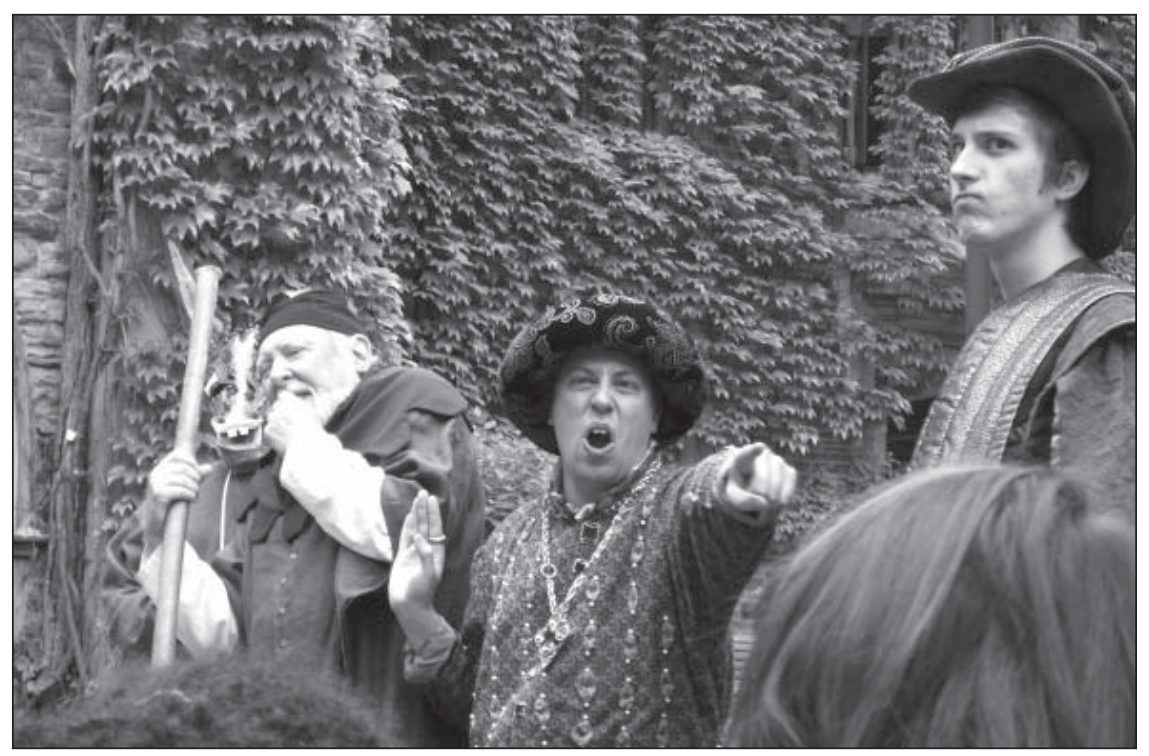

Fig. 4. Balaack (Duquesne University). Courtesy of Heather S. Mitchell.

enthusiasm became; people's faces broke into wide smiles and the applause at the end was thunderous. This for me captured the essence of Biblical drama: Abraham, Isaac, and Moses, God, an Angel, and the Expositor stood shoulder-to-shoulder as actors, rather than as 'characters', to join with the audience in a moment of pure joy and praise. It was a very human moment, and it wasn't perfect - there were some anxious chuckles, and a couple of missed notes - but it was absolutely beautiful.

In the next play, actors from Duquesne University presented the story of Balaam and Balaack. I found the separation of this episode from that of Moses to be one of the best editorial changes of the 1572/2010 cycle text, as it allowed this unique episode to stand alone. The story seemed unfamiliar to many audience members, and the delight was palpable - particularly among the younger spectators - as Balaam's ass began to speak, embarrassed at the occasional brays that crept into her conversation. The fairy-tale quality of the episode made it accessible to all; a passing wedding party, in full finery, even stopped to watch for a moment, amused by the prophet and his talking donkey.

Although many of the Chester 2010 productions provided lavish and/ or complex sets ('The Fall of Man', 'The Flood', and 'The Resurrection' 
particularly come to mind), the Duquesne group used an undressed wagon, with only a simple wooden chair serving as God's throne. God and his Angel were stationed on the wagon, rather than isolated on the high raised platform, while the action of Balaam and Balaack took place at ground level, winding its way through the crowds. This staging emphasized God's closeness to his creation. When Balaam was tempted by the idea of 'much winning', God's reprimand came swiftly, and his outstretched hands reached not only toward the prophet but toward the audience as well, reminding us that Chester's Old Testament God is quite willing to involve himself in the affairs of mankind.

But God's involvement also took a memorable physical form. In a production largely free of props and sets, the larger-than-life, six-foot broadsword wielded by the Angel was in many ways the dominant symbol. The sword elicited audible gasps as the Angel stepped into the street to prevent Balaam's journey and a few of those seated on the low wall that served as the 'front row' at station two shrank back visibly as the enormous weapon - a forceful reminder of God's power and might — descended only a foot or two away from their own heads.

The Chester 2010 audiences were treated to a gleeful tyrant in Balaack. Every inch a stereotypical medieval despot from the top of his brocade turban to the tips of his curly-toed shoes, Duquesne's Balaack preened and giggled, scampering through the audience and jovially anticipating the curses that would soon be visited upon his enemies. Watching Balaack, one could easily understand why tyrant figures were so popular with their original audiences. Unlike most of the tyrants in the weekend's performances, Balaack went out of his way to 'work the crowd': he spoke directly to the audience and met our eyes with a saucy glance. And rather than just directing curses at 'Judea' in general, he aimed them at individuals who laughed appreciatively as the tyrant ran past, muttering, 'I'm going to curse you $\ldots$ and you and you ... and don't think I've left you out .... The contrast between Balaack's hyperactive petulance and God's calm sovereignty offered the audience an opportunity to consider the differences between earthly power and divine authority, much as our predecessors in 1572 Chester may have done before us.

But out of all the weekend's performances, the production from Kent State University seemed most eager to reach out to its contemporary audience. This production was an upbeat take on one of the longest and most challenging portions of the 2010 cycle, a conflation of two plays in the extant texts, 
with episodes including the raising of Lazarus, the anointing of Christ's feet by Mary Magdalen, the entry into Jerusalem, Christ and the Moneylenders, and Judas's plot, and it certainly generated lots of conversation among the crowd on the grass at station two.

The audience watched these familiar stories play out in a modern idiom, but unlike the producers of 'The Shepherds' and 'The Nativity', the Kent State troupe did not attempt to recreate a specific cultural niche. Instead, they filled their production with people and props from throughout our contemporary world. Christ was dressed in khakis, t-shirt, and loose white shirt; Mary and Martha in flowing, patterned skirts; the female Annas and Caiaphas in brightly coloured business suits circa 1986; and Judas (the highlight of the play - a marvellous young actor who captured the frustration, entitlement, humour, and sycophancy of the role perfectly) in a dark three-piece suit and tie. The temple merchants offered wares including t-shirts that read 'Jesus is my Homeboy' and 'Yahweh or the Highway', as well as a large pile of stuffed pelicans that flew everywhere when the angry Christ up-ended their stalls (the end of the play saw several young children reluctant to give up the pelicans that they had claimed!). The Jerusalem into which Christ entered on a massive, rolling saw-horse 'donkey' was even demarcated by a large stone wall covered with graffiti; this particular set piece got the whole audience snickering, as those who understood the scrawled Latin phrases (such as 'uxor pilati pueros circumcisos amat') shared their translations with those around them. These familiar, iconic details gave the audience members reasons to interact and to energize one another. The crowd had had much to see and process by this point in the weekend, and while shade was plentiful farther back in the quad, those of us who were keen to stick it out down front in the baking sun were starting to flag a bit. During this play, I think, a true sense of communitas developed among the crowd. Conversations about Pilate's wife gradually shifted to other topics as the thirteenth wagon rolled on to the next station; introductions were made; snacks and sunscreen were shared among those who had been strangers just an hour ago. These relationships were enthusiastically renewed as the performances began on day three, when new friends looked for one another, eager to continue their conversations and colour commentary. This was, for me, the moment that Chester 2010 stopped being just a performance. This was the moment that it turned into something more.

To the widely varied audience gathered on the Victoria College quad, Chester 2010 provided something largely missing from twenty-first-century 


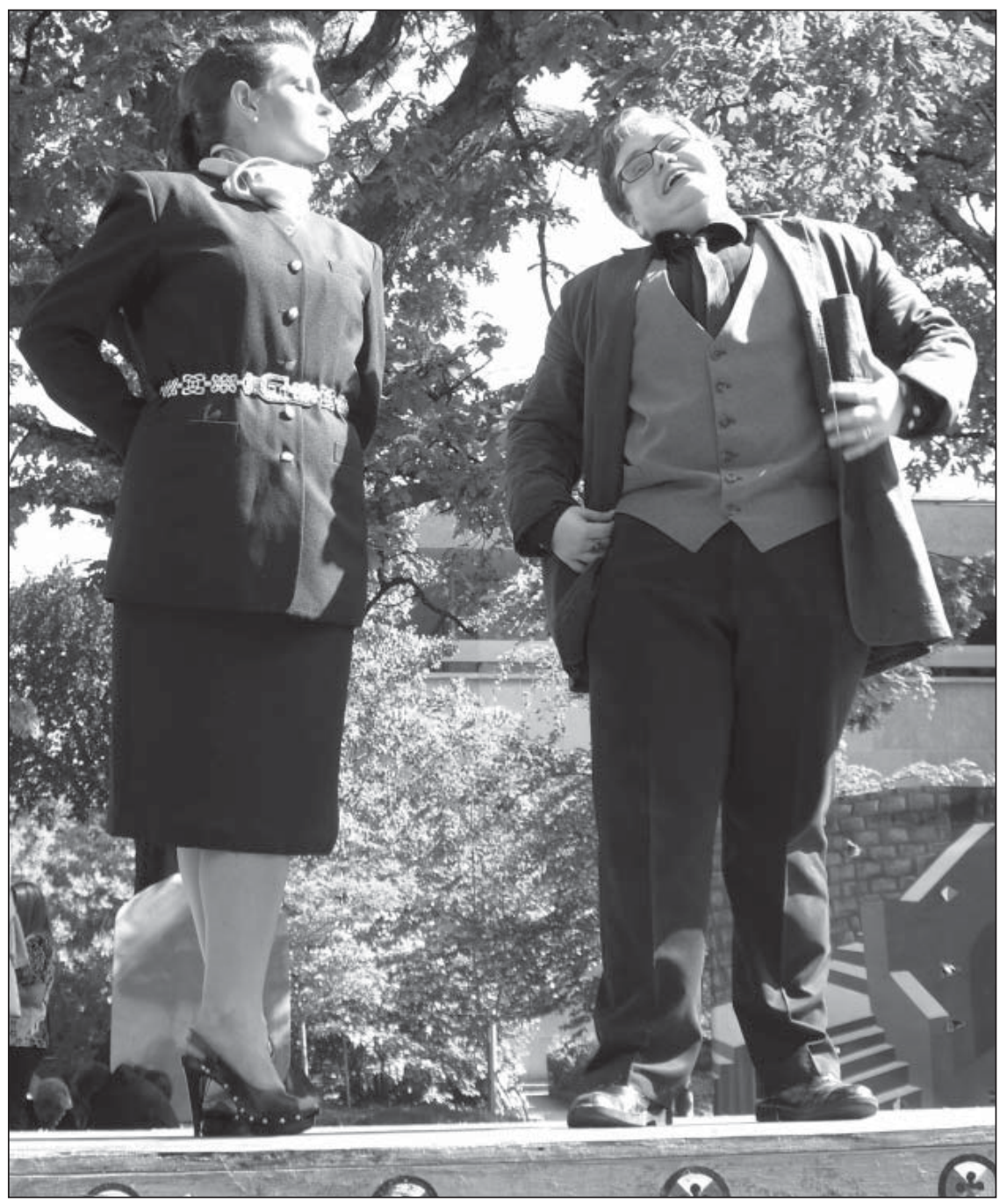

Fig. 5. Judas's Plot (Kent State University). Courtesy of Heather S. Mitchell.

life: a true sense of spectacle. Guy DeBord has characterized the spectacle of the modern world as one that demands 'passive acceptance' of the dominant social and economic order. The spectacle, he declares, 'is the bad dream of modern society in chains and ultimately expresses nothing more than its wish for sleep.' ${ }^{1}$ A true spectacle, however, offers a wake-up call, an invitation to see the world anew by looking at it not simply through our own eyes, but 
also through the eyes of those around us. The Chester cycle, whether in 1572 or in 2010, is indeed such a spectacle, and to participate in it was a joy and a pleasure.

Heather S. Mitchell

\section{Notes}

1 Guy Debord, Society of the Spectacle, trans. Ken Knabb (London, 2006), 10-12.

\section{Chester Heads South: 'Octavian' and 'The Shepherds'}

The plays of 'Octavian and the Nativity', performed by Shenandoah University, and 'The Shepherds', performed by the University of Illinois at UrbanaChampaign, constituted a dramatic study in contrasts. While both of these consecutive modern-dress productions reconfigured much of the content shaped by sixteenth-century Chester to suit a twenty-first-century United States, the ways in which the performances achieved this reconfiguration were as different as their levels of success. Done properly and thoughtfully, a modern-dress and modernized performance can bring out details of medieval and early modern drama that twenty-first-century audiences would otherwise miss. The original social and dramatic contexts can become relevant to audiences separated from the plays by culture and time via a reinscription that updates or even resists those contexts and, just as importantly, the plays can be both moving and fun. A less clear sense of direction can result in a performance that doesn't so much reinscribe the plays - transgressively or otherwise - as run roughshod over their sixteenth-century meaning in an effort to draw in a twenty-first-century audience.

Shenandoah University's 'Octavian and the Nativity' did a fine job of reinscribing the plays, bringing the class divisions and dialects of contemporary Appalachia to bear upon the text. The production gave careful attention to costume with a tuxedoed Octavian and surprisingly effective human ox and ass, but the highlight of this very well-acted performance was a rural Appalachian Mary and Joseph. Reaching beyond humour or mere contemporizing, actors Jenn Power and Michael Ehlers ably represented the reverent 